\title{
Molybdenum alloying in cast iron and steel
}

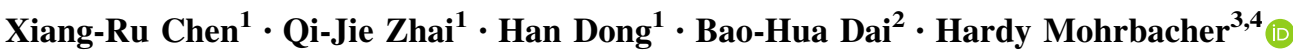

Received: 29 June 2019/Revised: 28 August 2019/Accepted: 25 October 2019/Published online: 10 December 2019

(C) The Author(s) 2019

\begin{abstract}
Metal casting is an important manufacturing technology for efficiently producing massive components with complex shape. A large share of industrial castings is made from iron and steel alloys, combining attractive properties and low production cost. Upgrading of properties in cast iron and steel is mainly achieved by alloying and in fewer cases by heat treatment. Molybdenum is an important alloying element in that respect, increasing strength, hardness and toughness. It also facilitates particular heat treatments such as austempering. The paper describes the metallurgical functionality of molybdenum alloying in iron-based castings and demonstrates its effectiveness for applications in the automotive and mining industry.
\end{abstract}

Keywords Grey cast iron - Nodular iron · Pearlite · Austempering - Creep resistance - Wear resistant alloys . Hardness · Toughness · Mining industry · Automotive industry

Xiang-Ru Chen

cxr16@shu.edu.cn

Hardy Mohrbacher

hm@niobelcon.net

1 School of Materials Science and Engineering, Shanghai University, Shanghai 200444, P.R. China

2 CITIC Machinery Manufacturing Inc., Houma 043011, Shanxi, P.R. China

3 Department of Materials Engineering, KU Leuven, 3001 Leuven, Belgium

4 NiobelCon bvba, 2970 Schilde, Belgium

\section{Introduction}

Casting technology is very attractive for producing industrial components as well as everyday-life household items. Since castings are manufactured to near-net shape, intensive machining is not required resulting in cost-efficient production of complex-shaped items. The casting process requires specific alloy compositions allowing good form filling, a low defect level as well as achieving the desired target properties after solidification and down-cooling [1].

Cast iron is a material with long history and tradition. According to the binary iron-carbon diagram, cast irons are alloys having more than $2.0 \%$ carbon, thus solidifying in the eutectic range with low melting point. Cast irons usually solidify following the stable iron-carbon diagram, thus forming graphite during solidification. In technical alloys the addition of carbon and silicon is combined to a socalled carbon equivalent $(\mathrm{CE}=\% \mathrm{C}+1 / 3 \% \mathrm{Si})$, which determines the range of cast irons according to Fig. 1 [2]. A CE of 4.3 represents a eutectic alloy while those with a lower $\mathrm{CE}$ and those with a higher $\mathrm{CE}$ are called hypoeutectic and hyper-eutectic, respectively.

The family of cast irons comprises six classes of materials according to the characteristics of graphite and matrix microstructure: Grey irons with lamellar graphite-GJL (DIN EN 1561), ductile or nodular irons with spheroidal graphite-GJS (DIN EN 1563), vermicular irons with compacted graphite-GJV (ISO 16112), white cast ironsGJN (DIN EN 126113), malleable irons-GJMB/GJMW (DIN EN 1562), austenitic irons-GJLA-X/GJSA-X (DIN EN 13835).

Considering a global production volume of over 70 million metric tons per year, grey irons $(64 \%)$ and ductile irons (35\%), have the largest market share by far [3]. Molybdenum alloying is applied in both classes of iron, 


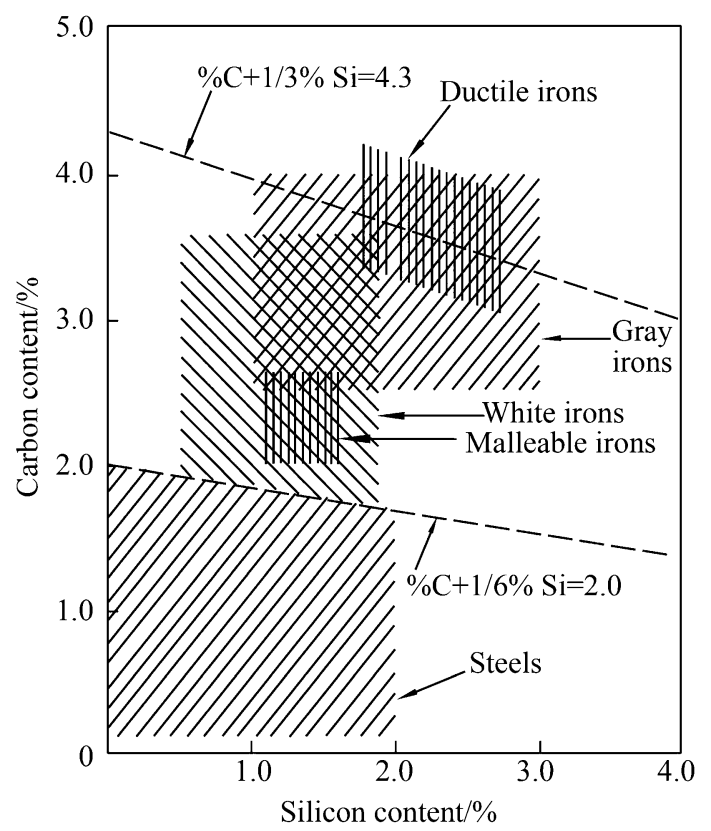

Fig. 1 Definition of cast iron alloys according to carbon and silicon contents [2]

typically for products with increased property demands. In particular cases, cast irons can be subjected to heat treatment after solidification for property improvement. The initial ferritic-pearlitic microstructure of the matrix is modified by so-called austempering to become bainitic with a high fraction of metastable retained austenite [4]. These irons are known as austempered ductile irons-ADI (DIN EN 1564) and austempered grey irons-AGI.

Cast steels are alloys where the combined addition of carbon and silicon $(\% \mathrm{C}+1 / 6 \% \mathrm{Si})$ is lower than $2 \%$ (see Fig. 1). Steel castings account for only about $1 \%$ of the global annual steel production. They are manufactured over a large variety of alloy compositions used in a multitude of applications. Thus, a high degree of specialization is involved with steel foundries. It can be stated that steel castings are preferred where manufacturing of a component starting from a wrought or rolled steel semi-product is too costly or too difficult. The different steel casting alloys can be distinguished according to the following application areas [5]: general applications (unalloyed C-Mn-Si steel), improved weldability and toughness for general purposes, high pressure purposes for use at low temperatures, high pressure purposes for use at room temperature and elevated temperatures, heat resistant steel castings, corrosion resistant steel castings, wear resistant steel castings.

Approximately half of the global annual castings output is produced by Chinese foundries [3]. The increasing demand for high-performance castings is driven by key industries such as the automotive, mechanical engineering and mineral processing sectors. The optimization of casting alloys typically involves a combination of properties to be considered. Applications in the automotive powertrain are demanding an improved combination of strength, heat conductivity and thermal fatigue resistance. In mineral processing optimized wear resistance is targeted, which is related to a suitable combination of hardness and toughness. The paper addresses the particular role of molybdenum alloying in this respect and highlights current alloy developments in China.

\section{Effects of molybdenum alloying in cast iron}

Molybdenum is known to act as carbide stabilizer in cast iron. At low addition level it has little effect on castability and chilling tendency. Free carbides are only formed at higher molybdenum addition. The amount and shape of graphite are not measurably affected by molybdenum additions below $0.5 \%$ [4, 5]. The main effect provoked by molybdenum alloying to cast iron is observed during solid state transformations. With increasing molybdenum alloy content, the pearlite phase field in the continuous cooling transformation (CCT) diagram is shifted towards longer times. Molybdenum addition up to around $0.5 \%$ acts a very powerful pearlite stabilizer and increases strength by refining pearlite [6, 7]. Higher molybdenum additions, preferably in conjunction with nickel or copper, promote the transformation from austenite into acicular ferrite. Such irons usually contain at least $0.8 \% \mathrm{Mo}$ and more than $1.2 \% \mathrm{Ni}$ [8]. The actual amount of alloy required depends upon the section thickness. The tensile strength of acicular irons is in the range of 400-500 MPa. They are more easily machinable at high levels of hardness (250-320 HB) than unalloyed irons due to the absence of free cementite.

Amongst the typical alloying elements, it is found that $\mathrm{Mn}$ and $\mathrm{Ni}$ coarsen the interlamellar spacing of pearlite, whereas an increasing content of $\mathrm{Cr}$ produces finer pearlite spacing. Si has only a slight influence on pearlite spacing. Molybdenum clearly has the strongest effect in decreasing the interlamellar spacing. The individual effect of these alloying elements on the pearlite interlamellar spacing, $S_{0}$, can be described as [9]

$$
\begin{aligned}
\log S_{0}= & -2.212+0.0514[\mathrm{Mn}]-0.0396[\mathrm{Cr}]+0.0967[\mathrm{Ni}] \\
& -0.002[\mathrm{Si}]-0.4812[\mathrm{Mo}]-\log \left(\Delta T / T_{\mathrm{e}}\right)
\end{aligned}
$$

where $S_{0}$ is measured in $\mu \mathrm{m}$; [Mn], [Cr], [Ni], [Si], [Mo] are the different alloy contents (mass fraction,\%); and $\Delta T$ is the undercooling from the eutectoid temperature $T_{\mathrm{e}}$. In pearlitic microstructures, the interfaces between ferrite and cementite act as barriers to dislocation movement [10]. The critical stress necessary to shift dislocations in ferrite lamellae is related to the macroscopic yield stress. That 
critical stress rises with the refinement of the pearlitic microstructure, since a decrease of pearlite interlamellar spacing leads to an increase in the resistance to glide according to a Hall-Petch type relationship. Furthermore, finer pearlite microstructures comprising smaller colony size and shorter interlamellar spacing, show a more ductile fracture character. This one is represented by a larger number of dimples as well as a smaller share of ferrite/ cementite lamellae in the fracture process zone [11].

\subsection{Grey cast irons}

Grey cast iron has limited strength and almost no ductility. Nevertheless, pearlitic grey cast iron is the preferred material for applications such as engine blocks, cylinder heads, flywheels or brake discs. This is reasoned by the low cost, good castability and favorable thermal conductivity of grey cast iron. Demands for higher thermal efficiency and weight reduction enabled by reducing component cross-sections require the development of high-performance grey cast iron with an improved combination of tensile strength and heat conductivity. However, those features promoting heat conductivity are typically detrimental to strength. The challenge is to find a suitable balance of microstructural design and hence alloy concept. The thermal conductivity of grey cast iron at ambient temperature ranges between $45 \mathrm{~W} /(\mathrm{m} \cdot \mathrm{K})$ and $55 \mathrm{~W} /$ $(\mathrm{m} \cdot \mathrm{K})$, whereas it is clearly lower for vermicular graphite iron $(32-42 \mathrm{~W} /(\mathrm{m} \cdot \mathrm{K}))$ and nodular iron $(25-35 \mathrm{~W} /(\mathrm{m} \cdot \mathrm{K}))$. However, when the temperature increases towards $500{ }^{\circ} \mathrm{C}$, the heat conductivity of grey cast iron declines while it remains nearly stable for vermicular and nodular iron [12]. Considering the matrix, ferrite has better heat conductivity than pearlite, yet the latter has higher strength. The heat conductivity of ferrite decreases with increasing alloy content. A higher volume share of graphite increases heat conductivity on expense of strength. A recent study indicated that the thermal conductivity was nearly independent of graphite flake length and aspect ratio above a threshold length of approximately $100 \mu \mathrm{m}$ [13]. From an alloying point of view, it appears favorable reducing the level of solute elements for improving thermal conductivity. In this respect, silicon is the most critical element. The use of a carbide stabilizer with good solubility and rather large atomic size is considered to be favorable [14]. Molybdenum exactly fulfils these conditions. Based on various published results it can be estimated that $0.1 \%$ addition of Mo increases the tensile strength by approximately $10 \mathrm{MPa}$. In synergy with other alloying elements such as for instance chromium, vanadium or niobium, the strengthening effect can be even larger. At elevated operating temperature, Mo-alloyed grey cast iron better retains strength and has clearly improved creep resistance $[6,15]$.

Table 1 compares thermal conductivity and strength of various iron alloys $[13,16]$. The grey iron alloys (GJL) have higher thermal conductivity and lower strength than vermicular graphite iron grades (GJV). However, an optimized near-eutectic grey iron grade (GJL-300 Mo HC) with reduced silicon content and $0.25 \% \mathrm{Mo}$ addition combines a tensile strength of over $300 \mathrm{MPa}$ with high heat conductivity. Raising the molybdenum content towards the earlier stated limit of $0.5 \%$ could further increase the strength [17].

Current grey iron grades according to typical automotive standards are represented in Fig. 2 showing that molybdenum alloying indeed provides superior strength in both hypo- and hyper-eutectic alloys. Niobium is a rather unconventional alloying element providing additional strength to grey cast iron. Unlike molybdenum, niobium affects the solidification structure and graphite morphology. Niobium additions up to around $0.3 \%$ were shown to refine the eutectic cell size as well as the pearlite interlamellar spacing (see Fig. 3) [18, 19]. This alloy concept is being used for the production of vehicle brake discs $[18,20]$. Systematic alloy variations in laboratory trials have indicated that the tensile strength of grey cast iron can be most efficiently increased by simultaneously refining the eutectic cell size and the pearlite interlamellar spacing (see Fig. 4) [21]. In that respect, the combined alloying of molybdenum and niobium has a particularly high strengthening potential. In this combination, molybdenum is providing additional refinement of pearlite interlamellar spacing and promotes precipitation strengthening by niobium.

\subsection{Nodular irons}

Nodular iron, in contrast to grey iron, contains graphite in form of isolated spheroids within a matrix consisting of ferrite or pearlite. This results in higher strength, good elongation and increased toughness as compared to iron containing lamellar graphite. Nodular irons are particularly interesting for manufacturing complex-shaped components used for engine or machine parts subjected to high acceleration or impact loads as well as for pressure pipes and vessels. Like in grey cast irons, molybdenum is added to nodular iron for further enhancing strength and also here additions up to $0.5 \%$ do not harm the graphite morphology or nodule count. Molybdenum added to nodular irons particularly enhances tensile, creep, and stress-rupture strengths at elevated temperature $[6,7,15]$. This has led to the development of SiMo irons containing 4\%-5\% silicon and $0.5 \%-1.0 \%$ molybdenum which can be used for component temperatures up to $820^{\circ} \mathrm{C}$. Such alloys are typically used for turbocharger housings of diesel engines. Silicon and molybdenum are complementary alloying elements with silicon providing oxidation resistance and raising the ferrite-to-austenite transformation temperature 
Table 1 Heat conductivity and tensile strength in grey iron (GJL) and vermicular graphite iron (GJV)

\begin{tabular}{llll}
\hline Grade & Alloy composition (mass fraction, \%) & $\begin{array}{l}\left.\text { Heat conductivity/(W·(m·K })^{-1}\right) \\
\left(@ 100{ }^{\circ} \mathrm{C} / 400{ }^{\circ} \mathrm{C}\right)\end{array}$ & $\begin{array}{l}\text { Tensile strength/MPa } \\
\left(@ 20{ }^{\circ} \mathrm{C}\right)\end{array}$ \\
\hline GJL-250 CrCu & $3.35 \mathrm{C}, 1.8 \mathrm{Si}, 0.5 \mathrm{Mn}, 0.3 \mathrm{Cr}, 0.5 \mathrm{Cu}$ & $42 / 38$ & 260 \\
GJL-300 Mo HC & $3.6 \mathrm{C}, 1.3 \mathrm{Si}, 0.3 \mathrm{Mn}, 0.25 \mathrm{Mo}$ & $50 / 43$ & 310 \\
GJV-350 & $3.5 \mathrm{C}, 2.5 \mathrm{Si}, 0.25 \mathrm{Mn}$ & $42 / 39$ & 350 \\
GJV-450 & $3.6 \mathrm{C}, 2.2 \mathrm{Si}, 0.4 \mathrm{Mn}, 0.8 \mathrm{Cu}, 0.06 \mathrm{Sn}$ & $38 / 36$ & 450 \\
\hline
\end{tabular}

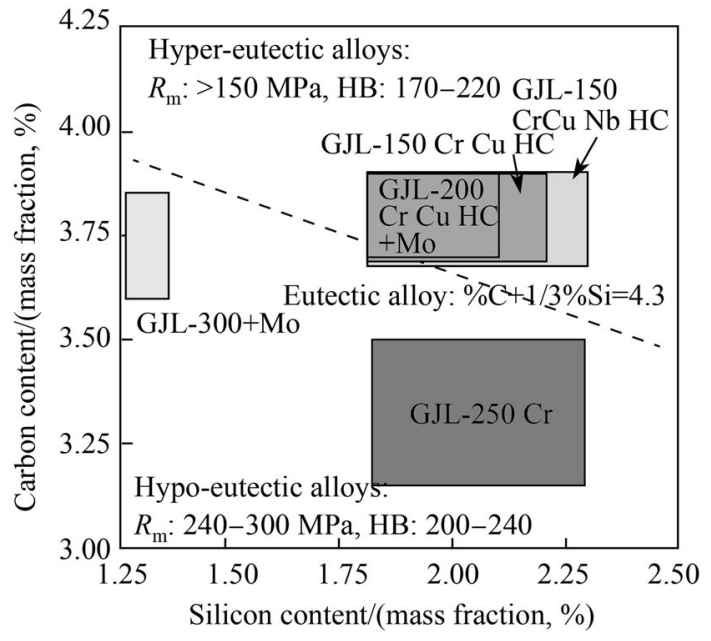

Fig. 2 Hypo- and hyper-eutectic alloy concepts of grey cast iron grades and specified mechanical properties according to European automotive standards

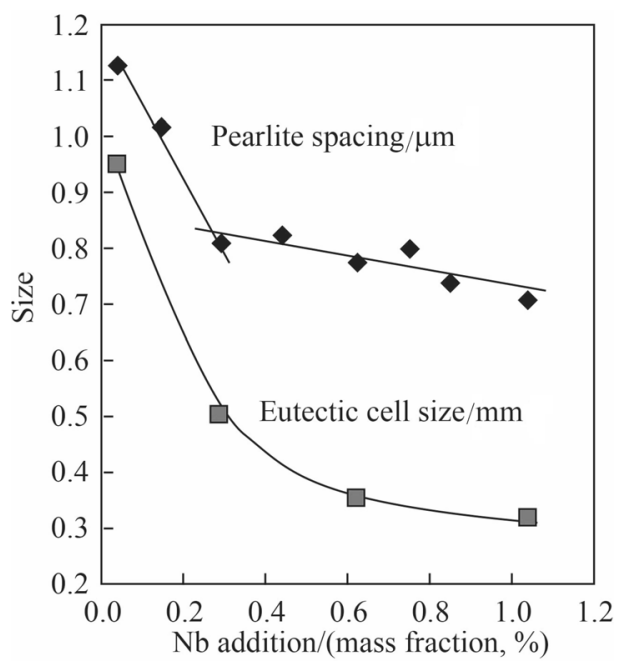

Fig. 3 Effect of niobium addition on microstructural refinement in grey cast iron [18]

$\left(A_{1}\right)$ while molybdenum increases the elevated temperature strength and creep resistance. Constrained thermal cycling tests of ferritic SiMo nodular iron demonstrated a strong beneficial effect of molybdenum [15]. A more recent

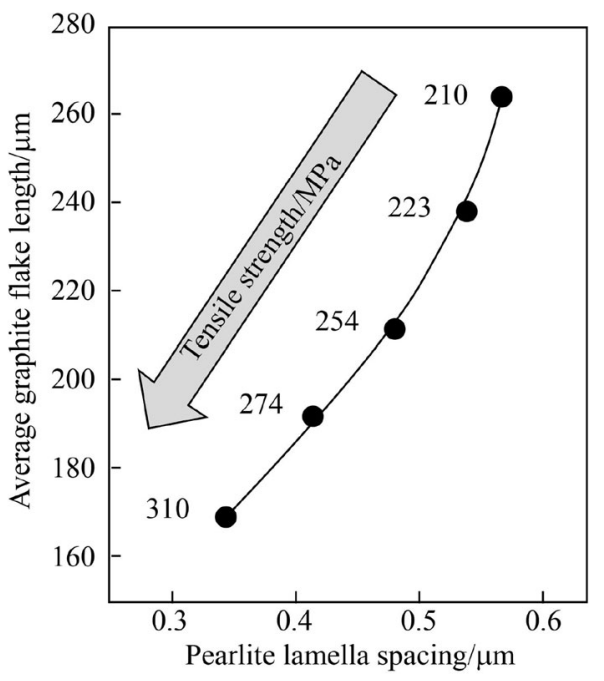

Fig. 4 Effect of microstructural refinement on tensile strength in grey cast iron based on laboratory results provided by Shanghai University [21]

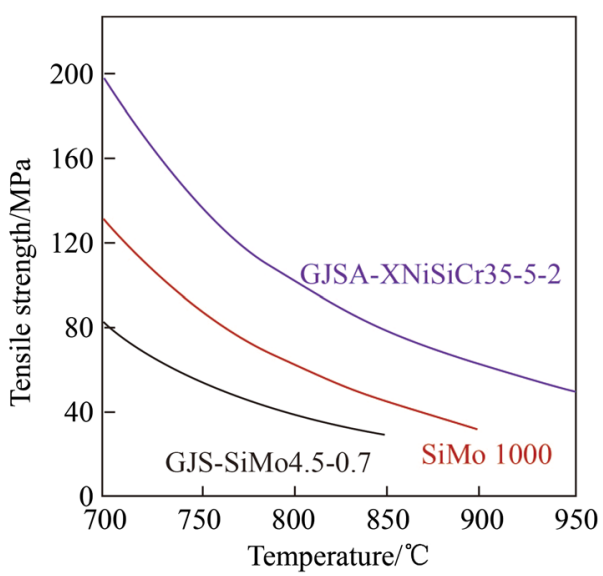

Fig. 5 Tensile strength at high temperature for SiMo iron alloys and austenitic cast iron Ni-resist D5S [22]

variant of SiMo iron (SiMo1000) is alloyed with around $1 \%$ molybdenum and a high aluminum addition of around $3 \%$ while silicon is reduced to $2.5 \%$ [22]. This alloy allows raising the operating temperature limit further to $860{ }^{\circ} \mathrm{C}$ 
(see Fig. 5). For even higher operating temperatures up to around $950{ }^{\circ} \mathrm{C}$, austenitic cast irons such as GJSA-XNiSiCr35-5-2 also known as Ni-Resist D5S can be used [23]. It should be noted that molybdenum additions to such austenitic irons have similar effects as in ferritic SiMo alloys.

\subsection{Austempered irons}

Austempering designates a heat treatment in which the ascast iron matrix is reheated into austenite upon which the iron is cooled in austenitic state to an isothermal holding temperature of around $300{ }^{\circ} \mathrm{C}$ [24]. The formation of pearlite during cooling must be avoided [25]. During austempering, an increasing fraction of bainite forms and carbon partitions to the remaining austenite phase. The highly carbon enriched austenite fraction remains metastable down to temperatures of $-80^{\circ} \mathrm{C}$. The final microstructure of austempered ductile iron (ADI) consists of bainite and retained austenite (also called ausferrite) as well as spherical graphite resulting in very attractive properties. Figure 6 schematically indicates the evolution of mechanical properties by modifying graphite morphology and austempering of the matrix representing the transition from grey cast iron to ADI [26, 27]. ADI achieves similar strength as heat-treated steel at $10 \%$ lower material density, and has high noise damping capacity and selflubricating properties in dry contacts. Toughness and elongation are better in ADI as compared to other cast iron materials at comparable strength. Accordingly, ADI is one of the most attractive construction materials for realizing weight reduction (see Fig. 7) [25]. The most significant use of ADI is found in vehicle and railway applications (see Fig. 8) [25, 26, 28, 29]. Some typical examples of truck and trailer components manufactured from ADI are shown in Fig. 9.

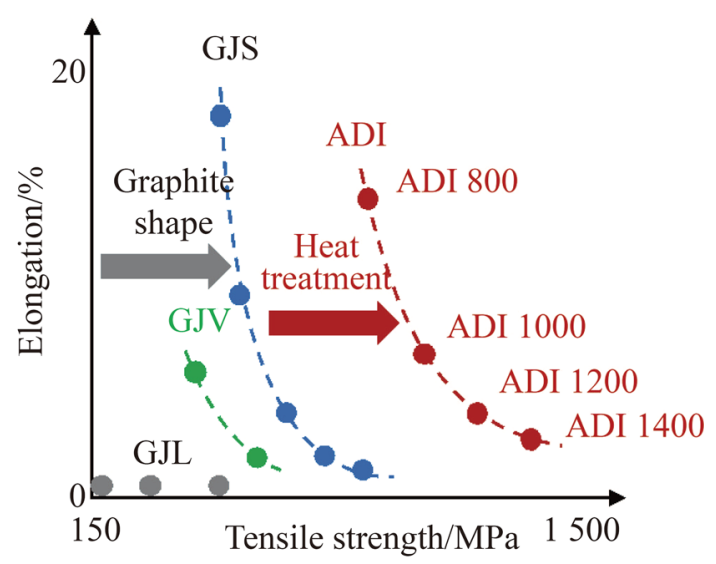

Fig. 6 Tensile characteristics of ADI in comparison to GJL, GJV and nodular iron (GJS) [26]

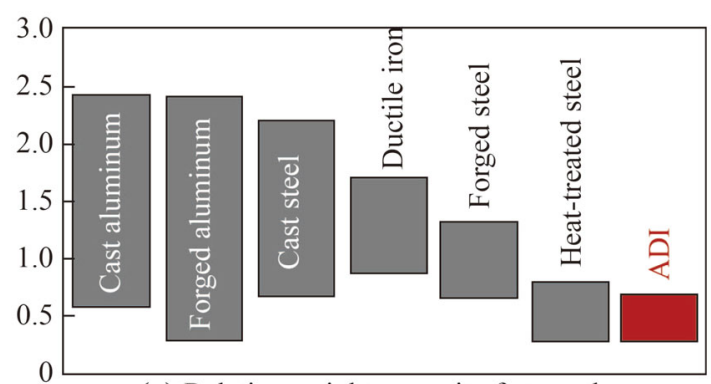

(a) Relative weight per unit of strength

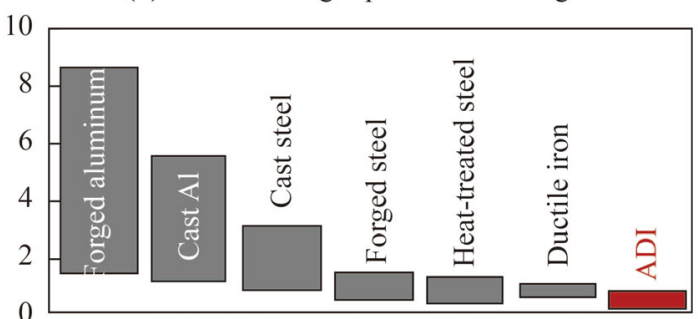

(b) Relative cost per unit of strength

Fig. 7 Comparison of light weighting potential and cost for materials used for manufacturing of massive components $[25,26]$
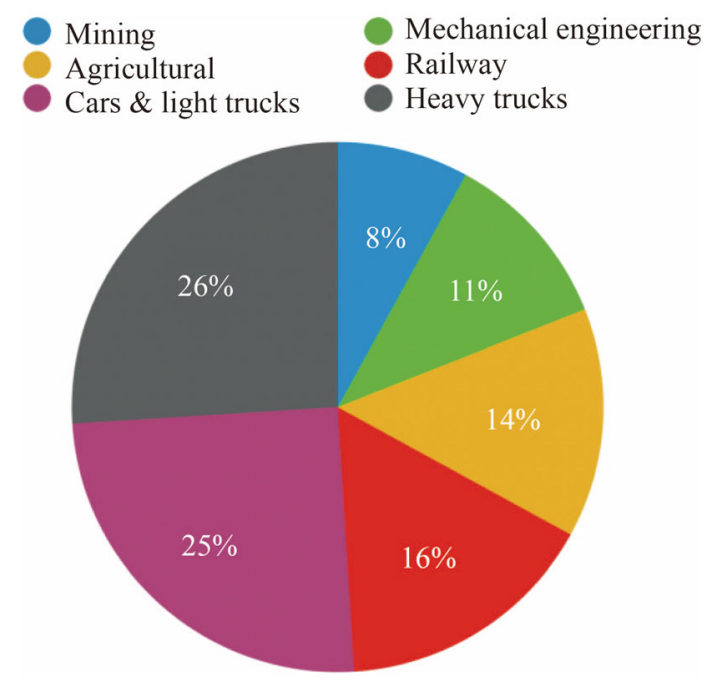

Fig. 8 Market share of major applications for ADI castings [29]

Molybdenum alloying is used to avoid pearlitic transformation during cooling to the austempering temperature avoiding the necessity for major capital investment in quenching facilities [30], especially when casting components with larger section size (see Fig. 10). Manganese is also an effective hardenability agent yet must be kept low (max. $0.3 \%$ ) to develop maximum elongation and toughness in ADI. Larger additions of nickel or copper could supply the required hardenability, but combined nickelmolybdenum or copper-molybdenum alloying is more effective because of the synergetic effects of these elements on hardenability [31]. The inherently high silicon 

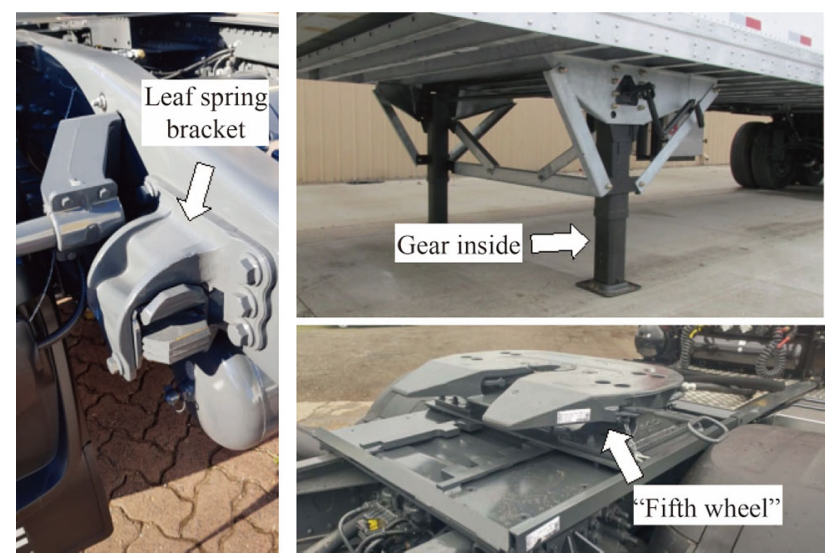

Fig. 9 Exemplary use of ADI components in trucks and semi-trailers

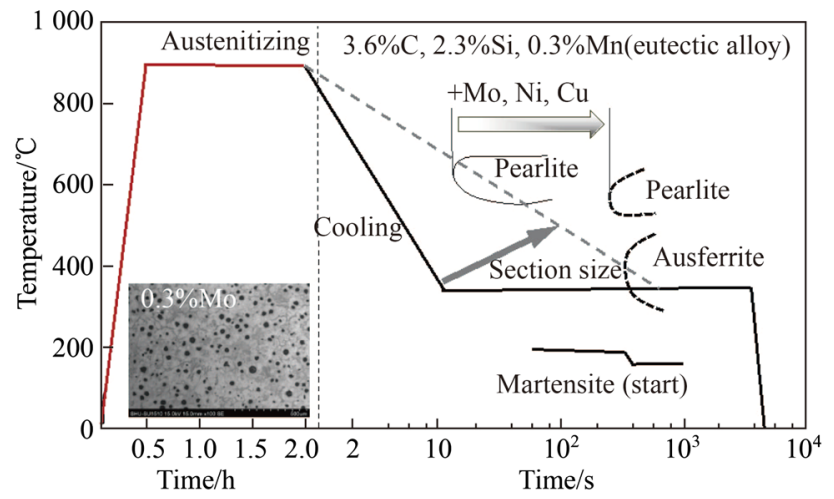

Fig. 10 Heat treatment cycle for austempering and effect of alloying elements on the matrix phase formation [25]

content inhibits carbide precipitation during austempering and thus helps stabilizing austenite.

Recent development activities at Shanghai University are focusing on further improving wear resistance of ADI. The approach intends reinforcing the ADI matrix with hard carbide particles. For this purpose, a Mo-alloyed base composition is co-alloyed with different levels of niobium. Niobium forms carbide particles, which precipitate already in the liquid phase when the concentration is larger than $0.2 \%$. The combination of Mo and solute $\mathrm{Nb}$ produces a fine-grained ausferrite resulting in improved toughness. Niobium additions above $0.6 \%$, however, deteriorate the graphite nodularity and reduce the nodule count [32]. The abrasion resistance was the highest for niobium addition in the range of $0.2 \%-0.6 \%$. The microstructural features for achieving performance optimization are the share of ausferrite in the matrix and the presence of dispersed carbide particles (see Fig. 11). The carbide particles embedded in the matrix act as a barrier to the detrimental action of abrasive particles (see Fig. 12).

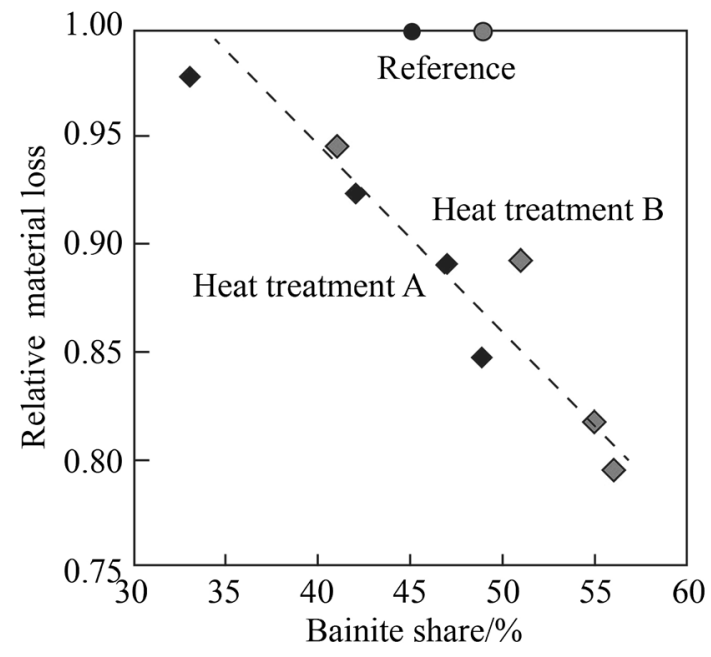

Fig. 11 Relative material loss of niobium alloyed material as a function of bainite share (the dashed line represents a linear fit of all samples with $\mathrm{Nb}$ addition (diamond symbol)) [32]

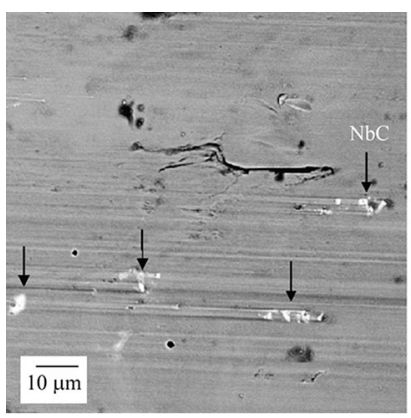

(a)

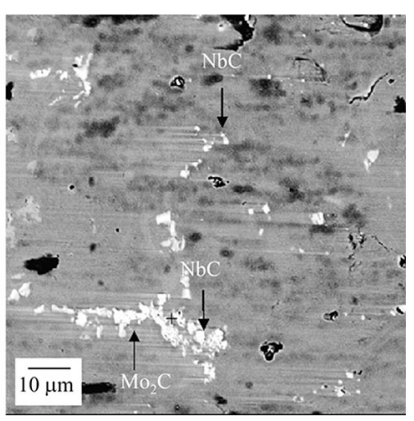

(b)
Fig. 12 Scanning electron micrographs of wear tracks in $0.55 \% \mathrm{Nb}$ alloyed ADI indicating a the obstruction of ploughing by dispersed $\mathrm{NbC}$ particles and b large-sized eutectic carbides formed by molybdenum segregation in the intercellular region [32]

\subsection{White cast iron}

Wear-resistant alloyed irons also known as "white cast irons" have found widespread application in the mining industry for the manufacturing of crushers, mill liners, and slurry pumps as well as for sleeves of work rolls. Simple white cast irons are extremely brittle and nearly impossible to machine. Adding chrome in the range of $12 \%-28 \%$, together with nickel and molybdenum, allows producing abrasion-resistant alloys that are tough and can be cast in large sizes to match the needs of the mining industry [33]. Eutectic carbides in the composition of $\mathrm{M}_{7} \mathrm{C}_{3}$ in combination with an austenitic, martensitic, or pearlitic matrix gives a full range of material design possibilities. Some of the components are cast with pearlitic matrix to allow machining and are subsequently heat treated to obtain an abrasion-resistant martensitic structure. The principal 
effect of molybdenum as an alloy addition to white cast iron is increasing the hardenability or austenite stability of these alloys. Not necessarily all of the molybdenum added is effective for hardenability since it was found to also participate in alloy carbides formed in these materials. Molybdenum can form carbides by itself as $\mathrm{Mo}_{2} \mathrm{C}$ if present in concentrations over $2 \%$. At lower concentrations it is soluble in $\mathrm{M}_{7} \mathrm{C}_{3}$ and $\mathrm{MC}$ carbides. $\mathrm{Mo}_{2} \mathrm{C}$ carbides have a hardness of $1500-1800 \mathrm{HB}$. Molybdenum is primarily used to stabilize the austenite during cooling after solidification and to prevent the formation of pearlite, similar as in the processing of ADI. Molybdenum has little effect on the martensite start $\left(M_{\mathrm{S}}\right)$ temperature, compared with other elements that tend to decrease the $M_{\mathrm{s}}$ temperature and over-stabilize the austenite phase [34]. Molybdenum additions less than about $1.0 \%$ have been found insufficient to suppress the formation of pearlite in heavy section castings, while amounts greater than $3.0 \%$ have no additional benefit in that respect. Molybdenum, if alloyed in conjunction with nickel, copper and manganese enhances the ability of suppressing pearlite. Combined alloying of molybdenum and niobium shows synergetic effects in delaying pearlite formation (see Fig. 13) and in increasing wear resistance [35].

White cast irons are the work horses of wear protection in the mining and cement industry, as well as in road construction where abrasion by mineral particles prevails. There are two main types of white irons. Ni-hard comes in 4 types covering hardness range from $200 \mathrm{HB}$ to $600 \mathrm{HB}$, depending on the Mo addition ranging from 0 to $1 \%$. The component thicknesses with such alloys is limited to up to $200 \mathrm{~mm}$. Casting of thicker-walled components, however, is possible with high-chrome-molybdenum alloys. In

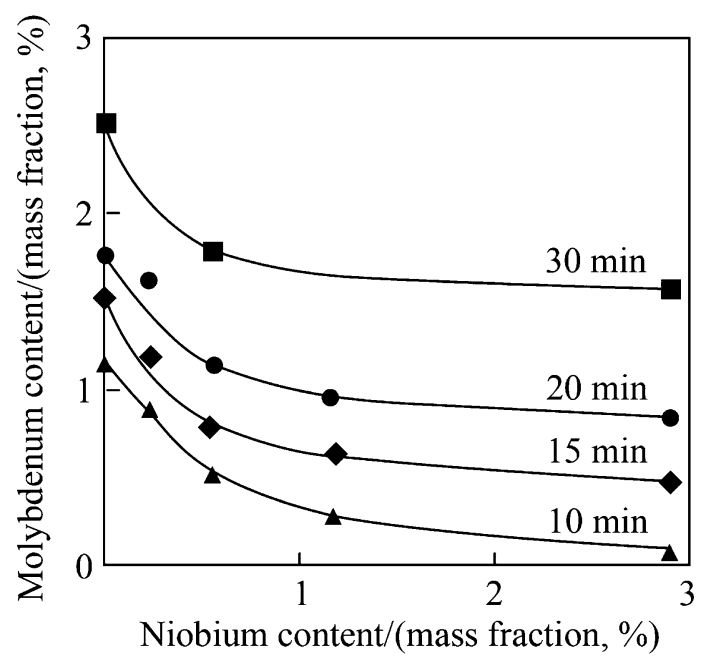

Fig. 13 Influence of $\mathrm{Mo}$ and $\mathrm{Nb}$ contents on the time for $5 \%$ pearlite transformation at $700{ }^{\circ} \mathrm{C}$ in $2.94 \% \mathrm{C}-16.7 \% \mathrm{Cr}-0.83 \% \mathrm{Mo}-0.72 \% \mathrm{Cu}$ white cast iron [35] chrome-molybdenum white irons a primary $(\mathrm{Cr}, \mathrm{Fe})_{7} \mathrm{C}_{3}$ carbide is being developed with a hardness of nearly twice that of quartz [27]. The $(\mathrm{Cr}, \mathrm{Fe})_{7} \mathrm{C}_{3}$ carbides in chromemolybdenum white irons are embedded in an austenite/martensite matrix providing the higher toughness [36]. A prominent example is the proprietary alloy Climax 15-3 containing $20 \%-27 \% \mathrm{Cr}$ and $0.5 \%-3.0 \%$ Mo [37]. This alloy is noticeably tougher and harder than Ni-hard iron grades. The linear abrasion rate of slurry pump impeller manufactured from Climax 15-3 exposed to a mixture of silica sand and water is multiple times lower than for a standard GG-25 grey iron alloy and still clearly superior to Ni-hard 4 (see Fig. 14) [38].

\section{Cast steel alloys}

The base composition of steel castings consists of carbon, manganese and silicon. Depending on the area of application, additional alloying elements such as $\mathrm{Cr}$, Mo and $\mathrm{Ni}$ are required [39]. In contrast to rolled steel grades, cast steels cannot be thermo-mechanically processed and must fully rely on heat treatments for developing a suitable microstructure providing high-performance properties. Molybdenum is used at levels up to $0.4 \%$ to give additional solid solution strengthening and to particularly increase hardenability when heat treating heavy sections. Nickel is added for solid solution strengthening and when good lowtemperature toughness is required. Chromium further increases hardenability. Microalloying elements such as $\mathrm{Nb}$ and $\mathrm{V}$ are typically added to control grain size and to provide precipitation strengthening [40]. The heat treatment of HSLA cast steels is often carried out in three stages being homogenization, austenitizing prior to normalizing or quenching and, finally, tempering or ageing. The homogenization treatment, usually done between $1000{ }^{\circ} \mathrm{C}$ and $1100{ }^{\circ} \mathrm{C}$ for holding times of up to $6 \mathrm{~h}$, reduces segregation of alloying elements after initial solidification especially in heavy sections. Accelerated cooling from the

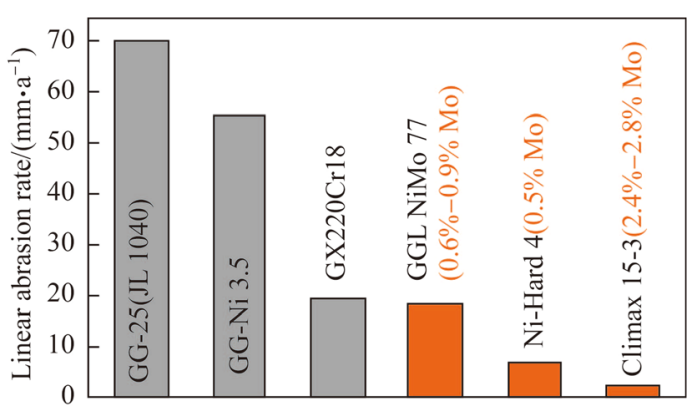

Fig. 14 Abrasion rates of various cast materials exposed to hydroabrasive wear in a silica-based slurry [38] 
Table 2 Materials used in the different stages of mineral ore processing [43]

\begin{tabular}{lllll}
\hline Processing stage & Equipment & Component & Alloy type & Microstructure \\
\hline Primary crushing & Primary crusher & Concaves and mantles & High-Mn steel & Austenitic \\
& & & Martensitic Cr-Mo steel (concaves) & Martensitic \\
Secondary and tertiary crushing & Cone crusher & Concaves and mantles & High-Mn steel & Austenitic \\
Grinding & SAG mill & Liners & Cr-Mo steel & Pearlitic \\
& & Balls & Low alloy Cr steel & Martensitic \\
& Ball grinding mill & Liners & High Cr white iron & Partensitic \\
& & & Cr-Mo steel & Martensitic \\
\hline
\end{tabular}

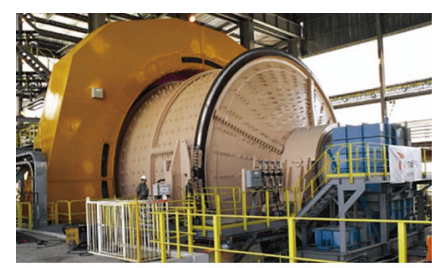

(a)

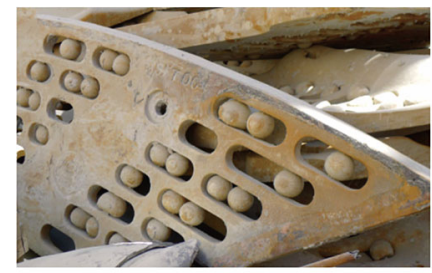

(c)

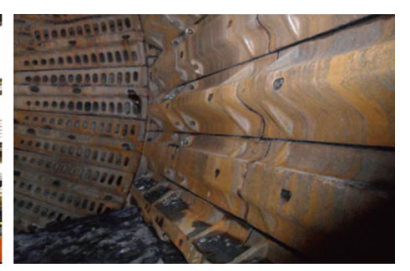

(b)

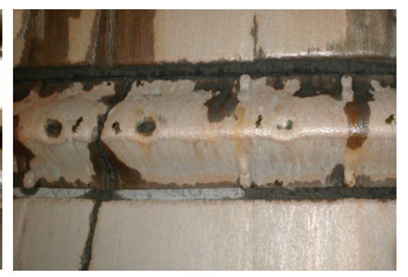

(d)
Fig. 15 a SAG mill with diameter of $12 \mathrm{~m}$, b inside the SAG mill showing liners and exit grate, $\mathbf{c}$ clogging of exit grate by grinding balls, $\mathbf{d}$ wear appearance on liner

homogenization temperature promotes the refinement of the ferrite grain in the final microstructure. The tempering treatment optimizes toughness and allows precipitation of solute microalloying elements [40].

The market need for wear resistance castings in China amounts to approximately 5 million tons per year [41]. Major consuming sectors are the mining, cement and thermal power industries. Table 2 shows the typically used alloy types and material microstructures applied for various components in mineral ore processing stages. The equipment being most relevant to this consumption of casting components are ball mills (see Fig. 15). Approximately $55 \%$ of the material is used for breaker balls and $11 \%$ for liners. Any improvement in the performance, i.e., enhanced durability of these components results in a high economic benefit. In a large-size dressing plant processing $100000 \mathrm{t}$ of ore per day, the typical service life of liners is experienced to be less than 6 months. Thus, significant additional costs are due to maintenance and replacement of components in autogenous (AG) or semi-autogenous (SAG) grinding mills. As an example, a large ball mill processing
50 million tons of ore per year has a down-time cost of about 300000 USD per hour [42, 43]. The typical average downtime for a maintenance term is about $20 \mathrm{~h}$. For a SAG mill plant processing 50 million tons of ore annually, the benefit of a $10 \%$ extension of grinding ball lifespan causes only a $2.0 \%$ increase in alloy cost but saves over 1.5 million USD per year in reduced maintenance. The consumption of SAG mill liners is less than that of grinding balls; nevertheless, the estimated indirect benefit from a liner lifespan increase of $10 \%$, is in the order of 1.7 million USD per year for an average SAG mill [43].

Ball grinding mill components can be manufactured by casting or by forging using rather similar steel alloys as shown in Table 3. In general, forged balls have a tempered martensite microstructure with retained austenite present throughout the entire section thickness. Cast grinding balls have a similar microstructure, yet with all of the characteristics of a cast section; chemical segregation and presence of discontinuities (pores, shrink holes, etc.). Thus, cast grinding ball have inferior mechanical properties making them unsuitable for use in SAG mills where failure by fracturing would occur due to high impact stresses. Ball consumption is mainly due to wear in ball grinding mills and also due to fracturing in SAG mills (approximately $10 \%$ ) [44]. In large-size SAG mills (1158.24-1219.2 cm in diameter), ball fracturing can account for a higher percentage of consumption due to increased impact energies. In these cases, the ball quality becomes more important. Balls that are deformed can clog the exit grates of the SAG mill (see Fig. 15c), leading to unplanned maintenance. The chemical composition of the Cr-Mo steel used in liners does not adhere to any particular standard. However, the large majority of the suppliers manufacture their products in a composition range as shown in Table 4. It should be noted that there has been virtually no change in these types of alloys over the recent decades. Liners are subject to high impact loads produced mainly by grinding balls of up to $15.24 \mathrm{~cm}$ in diameter. Hence, steel used for liners must be sufficiently tough to avoid fracture under normal operating 
Table 3 Alloys used for liners and grinding balls in a semi-autogenous ball mill [43]

\begin{tabular}{llllll}
\hline & $\mathrm{C} /($ mass fraction, \%) & $\mathrm{Mn} /($ mass fraction, \%) & $\mathrm{Cr} /($ mass fraction, \%) & $\mathrm{Si} /(\mathrm{mass}$ fraction, \%) & $\mathrm{Mo} /(\mathrm{mass}$ fraction, \%) \\
\hline Liners & $0.50-0.75$ & $0.75-1.00$ & $2.00-2.50$ & $0.40-0.60$ & $0.30-0.45$ \\
Forged balls & $0.55-0.90$ & $0.70-1.25$ & $0.37-1.20$ & $0.18-0.70$ & $0.00-0.20$ \\
Cast balls & $0.75-0.95$ & $0.40-1.10$ & $0.20-1.10$ & $0.30-0.60$ & Residual \\
\hline
\end{tabular}

Table 4 Alloy compositions and heat treatment conditions for laboratory optimization of liner steel [42]

\begin{tabular}{|c|c|c|c|c|c|c|c|c|c|}
\hline Steel & $\begin{array}{l}\mathrm{C} /(\operatorname{mass} \\
\text { fraction, \%) }\end{array}$ & $\begin{array}{l}\mathrm{Mn} /(\operatorname{mass} \\
\text { fraction, \%) }\end{array}$ & $\begin{array}{l}\mathrm{Si} /(\operatorname{mass} \\
\text { fraction, \%) }\end{array}$ & $\begin{array}{l}\mathrm{S} /(\operatorname{mass} \\
\text { fraction, \%) }\end{array}$ & $\begin{array}{l}\mathrm{P} /(\text { mass } \\
\text { fraction, \%) }\end{array}$ & $\begin{array}{l}\mathrm{Cr} /(\operatorname{mass} \\
\text { fraction, \%) }\end{array}$ & $\begin{array}{l}\mathrm{Mo} /(\operatorname{mass} \\
\text { fraction, \%) }\end{array}$ & $\begin{array}{l}\mathrm{Nb} /(\text { mass } \\
\text { fraction, \%) }\end{array}$ & Heat treatment \\
\hline 1 & 0.84 & 0.81 & 0.42 & 0.038 & 0.027 & 2.04 & 0.26 & - & $880^{\circ} \mathrm{C} / 8 \mathrm{~h}$ \\
\hline 2 & 0.84 & 0.80 & 0.36 & 0.028 & 0.030 & 2.18 & 0.30 & 0.028 & $550^{\circ} \mathrm{C} / 20 \mathrm{~h}$ \\
\hline 3 & 0.86 & 0.77 & 0.38 & 0.032 & 0.029 & 2.17 & 0.29 & - & $920^{\circ} \mathrm{C} / 8 \mathrm{~h}$ \\
\hline 4 & 0.85 & 0.66 & 0.43 & 0.024 & 0.028 & 2.24 & 0.30 & 0.025 & $550^{\circ} \mathrm{C} / 20 \mathrm{~h}$ \\
\hline
\end{tabular}

conditions. Additionally, abrasive wear occurring inside the mill is significant; therefore, wear resistance is definitely a required property for these alloys. Accordingly, it is important finding a good balance between toughness and hardness balance in these castings, which can be achieved by refining the pearlitic microstructure.

Recent research activities at Shanghai University have been focusing on the improvement of liner castings by varying alloy compositions and heat treatment procedures of pearlitic steel (see Table 4) [42]. Niobium was microalloyed for providing additional microstructural refinement. The alloys were austenitized at two different temperature levels $\left(880{ }^{\circ} \mathrm{C}\right.$ and $\left.920^{\circ} \mathrm{C}\right)$ followed by air cooling to room temperature and subsequently tempered at $550{ }^{\circ} \mathrm{C}$. The niobium added variants showed indeed a finer microstructure. This refinement of reduced lamellar spacing in the pearlite phase as well as an increased share of troostite and sorbite phases showed indeed better mechanical properties. It is also expected that niobium precipitates as ultra-fine $\mathrm{NbC}$ particles during the tempering treatment. As a result, the hardness increases from around $300 \mathrm{HB}$ in steel 1 and $3-350 \mathrm{HB}$ in the niobium added alloys (steels 2 and 4 in Table 4). Impact toughness is at around $50 \mathrm{~J}$ for all alloys whereas ductility (elongation, reduction of area) is improved in the niobium added materials. The hardness gain of around $16 \%$ is expected to improve the wear resistance in the same order of magnitude, which will result in a severe operating cost reduction for SAG mills, as was detailed before.

In another approach, a different alloy with lower carbon content and additional alloy content was designed as $0.4 \% \mathrm{C}-0.7 \% \mathrm{Si}-1.15 \% \mathrm{Mn}-1.7 \% \mathrm{Cr}-0.4 \% \mathrm{Mo}-0.3 \% \mathrm{Ni}-$

$0.07 \% \mathrm{~V}-0.02 \% \mathrm{Nb}[45]$. Heat treatments of this alloy were performed as detailed in Table 5. These treatments result in microstructures consisting of either a bainitic or a martensitic matrix containing retained austenite. The amount of martensite is controlled by the cooling-stop temperature after re-austenitizing at $880-900{ }^{\circ} \mathrm{C}$. The lowest cooling temperature produces the largest share of martensite resulting in the highest hardness, yet also in the lowest toughness (see Table 5). The differently treated steels were benchmarked in a grain-abrasion testing

Table 5 Mechanical properties and wear resistance (material loss) of $0.4 \% \mathrm{C}-0.7 \% \mathrm{Si}-1.15 \% \mathrm{Mn}-1.7 \% \mathrm{Cr}-0.4 \% \mathrm{Mo}-0.3 \% \mathrm{Ni}-0.07 \% \mathrm{~V}-0.02 \% \mathrm{Nb}$ after different austempering treatments [45]

\begin{tabular}{lllllll}
\hline Heat treatment (austempering) & Toughness $/\left(\mathrm{J} \cdot \mathrm{cm}^{-2}\right)$ & Hardness/HRC & \multicolumn{5}{l}{ Impact condition and material loss/g } \\
\cline { 5 - 7 } & & & $10000 \times 1.5 \mathrm{~J}$ & $20000 \times 1.5 \mathrm{~J}$ & $30000 \times 1.5 \mathrm{~J}$ & $10000 \times 2 \mathrm{~J}$ \\
\hline $880^{\circ} \mathrm{C} /$ oil $\rightarrow 500^{\circ} \mathrm{C} /$ air & 71.5 & 45.3 & 0.0938 & 0.2321 & 0.3554 & 0.1214 \\
$880^{\circ} \mathrm{C} /$ oil $\rightarrow 250^{\circ} \mathrm{C} /$ furnace & 46.5 & 52.3 & 0.0833 & 0.1803 & 0.2389 & 0.0856 \\
$900{ }^{\circ} \mathrm{C} /$ oil $\rightarrow 200^{\circ} \mathrm{C} /$ furnace & 35.3 & 53.6 & 0.0836 & 0.2103 & 0.2464 & 0.0950 \\
$880^{\circ} \mathrm{C} /$ oil $\rightarrow 325^{\circ} \mathrm{C} /$ air & 62.9 & 50.6 & 0.0832 & 0.2064 & 0.2319 & 0.0905 \\
\hline
\end{tabular}


machine (type MLD-10A) using impact energies of $1.5 \mathrm{~J}$ and $2 \mathrm{~J}$ as they typically occur in a large-size SAG mills. The material loss of the liner steel samples was monitored for a period of up to 30000 impacts. The results in Table 5 show that the softest steel (45.3 HRC), despite its high toughness $(71.5 \mathrm{~J})$, has the lowest wear resistance. The other steels, with the hardness exceeding 50 HRC perform clearly better, having 25\%-30\% reduced material loss under the same test condition. It appears that the best balance between hardness (52.3 HRC) and toughness $(46.5 \mathrm{~J})$ results in superior performance. Compared to the pearlitic steels in Table 5, the austempered steels (see Table 5) have a much higher hardness at similar toughness and hence offer a significant optimization potential.

\section{Conclusions}

Molybdenum alloying to iron-based castings offers several benefits in terms of improving the product properties for demanding applications. In products with pearlitic microstructure, molybdenum refines the pearlite lamellar spacing, thus, increasing strength and improving toughness. Favorable combinations of heat conductivity and strength become possible in that way particularly in grey cast iron. The most prominent roles of molybdenum alloying in nodular irons are to enhance the creep resistance under high temperature conditions and to facilitate hardenability. The latter is required for austempering treatment of components with heavier wall gage. Molybdenum's hardenability effect is also favorable for producing white cast iron to increase the wear resistance of components. Molybdenum shows synergies with other alloying elements such as niobium, chromium, copper and nickel reflecting in improved hardenability. The Mo-Nb synergy particularly results in more efficient refinement of the microstructure and enhanced precipitation strengthening of niobium. Property improvement of castings results in significant savings of operating cost especially with components used in large-sized capital equipment. Better creep resistance and higher strength in vehicle components increase their durability and inherently contribute to improved fuel efficiency. The further development of casting alloys in this respect is of strategic importance for the progress of mining, power generation, transport and machine building industries in China.

Open Access This article is distributed under the terms of the Creative Commons Attribution 4.0 International License (http://crea tivecommons.org/licenses/by/4.0/), which permits unrestricted use, distribution, and reproduction in any medium, provided you give appropriate credit to the original author(s) and the source, provide a link to the Creative Commons license, and indicate if changes were made.

\section{References}

1. Wang ZF, Yao M, Zhang XB et al (2013) Optimization control for solidification process of secondary cooling in continuous casting steel. Appl Mech Mater 263-266(3):822-827

2. Wayman ML (2003) Cast iron metallurgy. CASTI metals black book. 2nd edn. CASTI Publishing Inc, Edmonton, pp 67-132

3. WFO global foundry report 2018. World Foundry Organization 2018. www.foundrygate.com

4. Gundlach RB, Janowak FJ, Bechet S et al (1985) Mater Res Soc Symp Proc 14:399-409

5. Steel Founders's Society and ASM International (1995). In: Blair M, Stevens TL (eds) Steel castings handbook, 6th edn. https://doi. org/10.1361/schb1995p1-1

6. Gundlach RB (1978) Elevated-temperature properties of alloyed gray irons for diesel engine components. AFS Trans 86:55-64

7. Fairhurst W, Röhrig K (1974) Abrasion-resistant high-chromium white cast irons. Foundry Trade J 136:685-698

8. Angus HT (1976) Cast iron: physical and engineering properties. 2nd edn. Butterworths, London, pp 176-187

9. Capdevila C, Caballero FG, Garcia de Andres C (2005) Neural network model for isothermal pearlite transformation. Part I: interlamellar spacing. ISIJ Int 45(2):229-237

10. Dollar M, Bernstein IM, Thompson AW (1988) Influence of deformation substructure on flow and fracture of fully pearlitic steel. Acta Metall 36:311-320

11. Toribio J, González B, Matos JC et al (2016) Influence of microstructure on strength and ductility in fully pearlitic steels. Metals 6:318. https://doi.org/10.3390/met6120318

12. Holmgren D, Kallbom R, Svensson I (2007) Influences of graphite growth direction on the thermal conductivity of cast iron. Metall Mater Trans A 38(2):268-275

13. Liu YZ, Xing JD, Li YF et al (2018) Tomographical study of the effect of graphite on properties of cast iron. Steel Res Int. https:// doi.org/10.1002/srin.201800086

14. Bertodo R (1970) Grey cast irons for thermal stress applications. J Strain Anal 5(2):98-109

15. Gundlach RB (1979) Thermal fatigue resistance of alloyed gray irons for diesel engine components. AFS Trans 87:551-560

16. Druschitz AP, Fitzgerald DC (2000) Lightweight iron and steel castings for automotive applications. In: Proceedings of SAE 2000 world congress, Detroit MI, paper 2000-01-0679

17. Turnbull GK, Wallace JF (1959) Molybdenum effect on gray iron elevated temperature properties. AFS Trans 67:35-46

18. Mohrbacher H, Zhai Q (2011) Niobium alloying in grey cast iron for vehicle brake discs. In: Materials science and technology (MS\&T) 2011, processing, microstructure and properties of cast irons and cast and forged specialty steels, pp 434-445

19. Campomanes E, Goller R (1973) Effects of $\mathrm{Cb}$ addition on the properties and structure of gray iron. AFS Trans 81:122-125

20. Zhou W, Zhu H, Zheng D et al (2011) Niobium alloying effect in high carbon equivalent grey cast iron. China Foundry 8(1):36-40

21. Mohrbacher H (2018) On the metallurgical effects of niobium in cast iron alloys. In: WFO 2018 conference, Suzhou, China, pp 1-6

22. Kleiner S, Track K (2010) SiMo 1000—cast iron alloyed with aluminium for application at high temperatures. Giesserei Rundschau 11(12):229-234

23. Röhrig K (2004) Austenitische Gusseisen. konstruieren + giessen 29 Nr. 2:2-32

24. Tanaka Y, Kage H (1992) Development and application of austempered spheroidal graphite cast iron. Mater Trans 33:543-557

25. Harding RA (2007) The production, properties and automotive applications of austempered ductile iron. Kovove Mater 45:1-16 
26. Keough JR, Hayrynen KL, Pioszak GL (2010) Designing with austempered ductile iron (ADI). In: AFS proceedings, paper 10-129, American Foundry Society, Schaumburg, IL USA

27. Berns H, Theisen W (2008) Eisenwerkstoffe-Stahl und Gusseisen, 4th edn. Springer, Berlin. https://doi.org/10.1007/978-3540-79957-3

28. Keough JR, Hayrynen KL, Pioszak GL (2010) Designing with austempered ductile iron (ADI). In: AFS proceedings 2010. American Foundry Society, paper 10-129

29. Klöpper C, Bartels C, Schliephake U (2004) Strong benefits in weight reduction by the use of ADI. Konstruktion. VDI Verlag, Heft 7-8

30. Mi Y (1995) Effect of $\mathrm{Cu}, \mathrm{Mo}, \mathrm{Si}$ on the content of retained austenite of austempered ductile iron. Scr Metall 32:1313-1317

31. Semchysen M (1983) Recent developments on the role of molybdenum in irons and steels. In: Comins NR, Clark JB (eds) Specialty steels \& hard materials. Pergamon Press, Oxford, pp 87-110

32. Chen X, Zhao L, Zhang W et al (2019) Effects of niobium alloying on microstructure, toughness and wear resistance of austempered ductile iron. Mater Sci Eng A 760:186-194

33. Fulcher JK, Kosel TH, Fiore NF (1983) The effect of carbide volume fraction on the low stress abrasion resistance of high $\mathrm{Cr}$ Mo white cast irons. Wear 84:313-325

34. Vermeulen WG, Morris PF, De Weijer AP et al (1996) Prediction of martensite start temperature using artificial neural networks. Ironmak Steelmak 23(5):433-437

35. Guesser WL (1985) Niobium in high-chromium irons. Foundry Manag Technol 113(9):50-52

36. Loper CR, Baik HK (1989) Influence of molybdenum and titanium on the microstructures of $\mathrm{Fe}-\mathrm{C}-\mathrm{Cr}-\mathrm{Nb}$ white cast irons. Trans AFS 97:1001-1008

37. Dougall JR (1974) An approach to mill liner materials for critical grinding service. In: Barr QE (ed) Proceedings of symposium materials for the mining industry. Climax Molybdenum Co., Greenwich, pp 169-172

38. KSB AG Company Brochure: cast materials from KSB, Pegnitz (Germany). www.ksb.com

39. Albright DL, Dunn DJ (1983) Wear behavior of iron and steel castings for the mining industry. JOM 35(11):23-29

40. Tither G (2001) Niobium in steel castings and forgings. In: Proceedings of the international symposium niobium 2001, Orlando, USA. TMS, pp 845-872

41. China Industry Research Institute (2018) Research and analysis of current situation and forecast of development trend of China's casting industry in 2019. China Industry Research Network, pp 35-36

42. Chen X, You M, Guo A et al (2018) Influence of niobium on the microstructure and properties of CrMo cast steel for liner plate. In: Mohrbacher H (ed) Proceedings of international symposium on wear resistant alloys for the mining and processing industry. TMS, pp 393-406

43. Pérez V, Villaseca D (2018) Opportunities for ferrous alloys used in copper mining. In: Mohrbacher H (ed) Proceedings of international symposium on wear resistant alloys for the mining and processing industry. TMS, pp 1-18

44. Sepúlveda JE (2006) Criteria for the selection, application and evaluation of grinding mill media. In: Paper presented at the first international ore processing meeting, Antofagasta, Chile, 26-28 July, 2006

45. Zhai CC (2018) Research on microstructure and properties of V-wear-resistant steel for lining board. Dissertation, Shanghai University

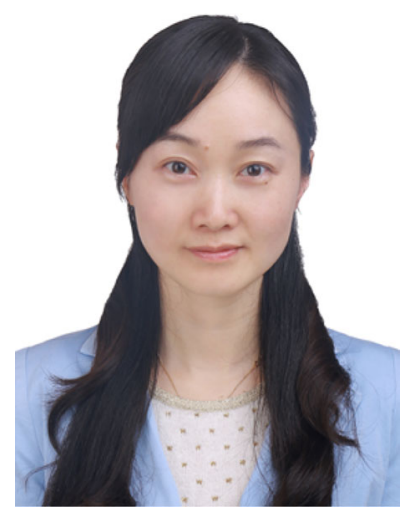

Xiang-Ru Chen is mainly engaged in research of highperformance cast steel materials using special alloying by niobium, vanadium, and rare earth elements. She has been involved in the development of wear-resistant steel, heat-resistant steel, low temperature steel, cast iron, aluminum alloys. She has supervised one project of the National Natural Science Foundation of China as well as several industrial projects. She published more than 40 papers in domestic and foreign journals. She won one provincial and local science and technology award and applied for 8 patents. She is member of the automotive materials branch of the Chinese Society of Automotive Engineering, the cryogenic steel branch of the Chinese Society of Metals, the wear-resistant materials branch of China, and the editorial board of Modern Cast Iron magazine.

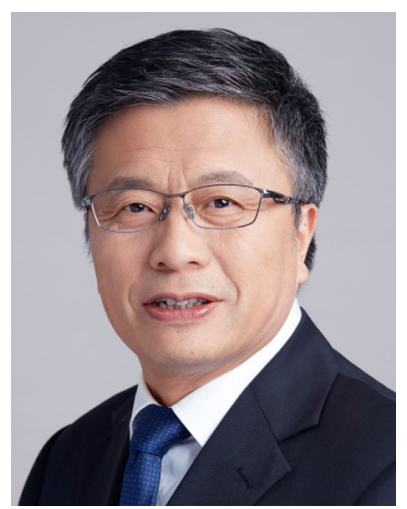

Qi-Jie Zhai is the director of the Advanced Solidification Technology Center of Shanghai University, vice chairman of the China Foundry Society, director of the China Institute of Foundry Journal Workmen's Committee, and member of the World Foundry Organization (WFO) Ferrous Metals Technical Committee. He is editorial board member of 13 academic journals. 4 original technologies, including thermal simulation of metal solidification, homogenization of pulse magnetically induced oscillation, nucleation of double disturbances of temperature and composition, and engineering materials of solidification metastable phase and super performance, are proposed. 9 new foundry products, such as centrifugal casting double metal compound roll ring, are developed. 11 technical achievements have been put into application. He has supervised over 80 projects, filed 89 patent applications, published 466 academic papers, published 2 monographs. He was honored with 7 provincial science and technology awards and 1 national technical invention award.

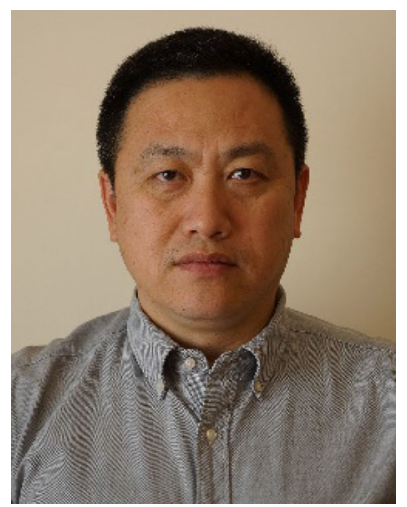

Han Dong is Professor and Dean of the School of Materials Science and Engineering of Shanghai University. He also is Research fellow of the Central Iron \& Steel Research Institute. He has been working in research of steel science and technology for over 30 years. He studied and proposed Deformation Induced Transformation (DIT) phenomenon and Multiphase, Metastable and Multiscale (M3) principal to control the microstructure evolution of steel and improve the performances. Novel steels, such as micron steel, medium manganese auto sheet steel, high toughness/ductility HSLA 
steel plate, delayed fracture resistant steel, and fatigue failure resistant steel have been developed under his guidance. He was granted 58 patents, published 458 journal papers and two books and edited two special issues in journals.

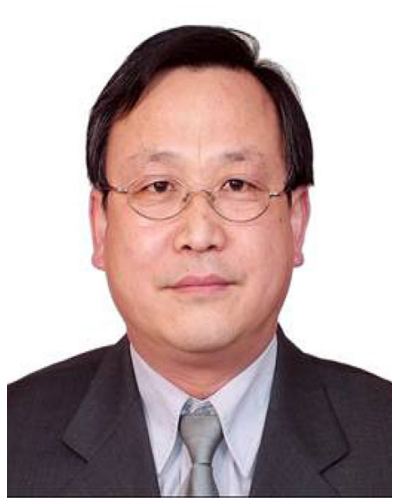

Bao-Hua Dai is the Chief Engineer of CITIC Machinery Manufacturing Inc. where he has worked since 1982. He has long years of experience in practical production and casting process. During his career, he has held senior roles in many development and innovation projects, especially in recent years, like cast steel brake disc for high speed train, casting device of track shoe (obtain of 6 practical patents), performance test of casting material of node for marine use and structure design, preparation method of nodular cast iron and riser structure design of fixed casting mandrel under atmospheric pressure. He is a technical expert of Shanxi Foundry Society.

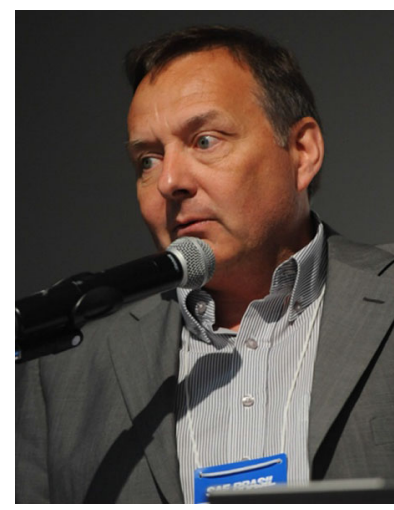

Hardy Mohrbacher specializes in materials and mechanical engineering including steel alloy design and processing, sheet metal forming and welding, automotive body design, non-destructive testing and materials characterization, plus the tribology of hard materials. He has written and co-authored over 200 scientific publication in the respective areas. He has held senior positions within, among others, Fraunhofer Institute for Nondestructive Testing (IZFP), Sidmar (ArcelorMittal Ghent) and ThyssenKrupp (TKTB). $\mathrm{He}$ is an Associate Professor at KU Leuven in Belgium and an Adjunct Professor at China's Shanghai University. Since 2007 he is owner and managing director of NiobelCon bvba, a consulting company focusing on steel alloy design, metallurgical processing and steel applications. 